\title{
Miastenija ir Lambert-Eaton miasteninis sindromas, juc gydymo rekomendacijos ir ypatumai COVID-19 pandemijos metu
}

\author{
A. Klimašauskiené* \\ R. Bunevičiūtè $* *$ \\ *Vilniaus universiteto Medicinos \\ fakulteto Klinikinès medicinos \\ instituto Neurologijos \\ ir neurochirurgijos klinika, \\ Neurologijos centras \\ **Vilniaus universiteto ligonines \\ Santaros kliniku \\ Neurologijos centras
}

\begin{abstract}
Santrauka. Miastenija ir Lambert-Eaton (LEMS) miasteninis sindromas yra autoimuninės neurologinės ligos, kurios pasireiškia raumenų silpnumu ir patologiniu nuovargiu. Miastenija yra dažniausia neuroraumeninè liga, o LEMS - labai retas susirgimas. Abi ligos simptomiškai gydomos acetilcholinesterazės inhibitoriais, LEMS - dar ir 3,4 diaminopiridinu ir amifampiridinu, o ilgalaikiam gydymui skiriami imunosupresiniai vaistai: gliukokortikoidai, azatioprinas, kiti imunosupresantai. Timektomija pacientams su timoma ir atrinktai grupei be timomos yra esminis gydymo metodas, taikomas sergant miastenija. Abiejų ligų paūméjimai gydomi intraveniniais imunoglobulinais ar gydomosiomis aferezėmis. Miastenijos ir LEMS gydymą pandemijos metu rekomenduojama pradèti ir tęsti pagal bendras rekomendacijas. Jei pacientams skirta imunosupresantų, šis gydymas turètų būti tęsiamas, nes nauda yra didesnė už galimą žalą. Gydymas imunosupresantais nutraukiamas tik išsivysčius sunkiai infekcijai.
\end{abstract}

Raktažodžiai: miastenija, Lambert-Eaton miasteninis sindromas, gydymas, COVID-19.

\section{MIASTENIJOS PAPLITIMAS IR PATOGENEZE்}

Miastenija (angl. Myasthenia gravis, sunkioji miastenija) yra autoimuninè liga, kurios metu gaminami antikūnai prieš posinapsinès membranos struktūras.

Miastenija - dažniausia iš neuroraumeninių ligų. Ja serga, įvairių tyrimų duomenimis, 25-142 gyventojai iš 1 milijono [1], liga nepakankamai diagnozuojama. Pirmieji simptomai gali būti pastebėti bet kuriame amžiuje, tačiau išskiriami du susirgimų pikai: 20-30 m. amžiaus asmenys, tarp kurių vyrauja moterys, po to naujų susirgimų palaipsniui daugeja, kol pasiekiamas kitas pikas 50-60 m. amžiaus grupejje, tada jau liga kiek dažniau diagnozuojama vyrams [2]. Miastenijos atvejų daugèja, nes dideja sergančiųjų vyresniame amžiuje [3].

Liga žinoma jau labai seniai. Pirmą kartą miastenija galimai aprašyta $1685 \mathrm{~m}$., o kaip atskira liga išskirta $1878 \mathrm{~m}$.

\author{
Adresas: \\ Aušra Klimašauskienè \\ VUL Santaros kliniku Nervu ligu skyrius \\ Santarišku 2, LT-08661 Vilnius \\ El.paštas ausra.klimasauskiene@santa.lt
}

W. Erb ir 1893 m. S. Goldflam. Miastenijos autoimuninè prigimtis galutinai įrodyta tik 1973 m. (J. Patric, V. Lennon, A. Engel darbai) [4].

Pagrindiniai antikūnai, kurie nustatomi, sergant miastenija, yra antikūnai prieš acetilcholino receptorius (AchR) - $85 \%$ atvejų, iš likusiujjų atvejų iki $50 \%$ randami antikūnai prieš raumenims specifinę tirozino kinazę (angl. muscle-specific tyrosin kinase, MuSK), baltymą, kuris yra svarbus AchR susigrupavime ir reikalingas ju funkcijai palaikyti $[3,5,6]$. Taip pat jau nustatomi antikūnai prieš agrino receptorių LRP4 (su žemo tankio lipoproteino receptoriumi susijusi 4-tą proteiną), molekulę, kuri sudaro jungini su MuSK [7]. Antikūnų prieš AchR gamyba siejama su užkrūčio liaukos ( $g$ l. thymus) pažeidimu, nes po timektomijos pagereja miastenijos simptomai, o histologiniai pakitimai, pašalinus čiobrialiaukę pacientams, sergantiems miastenija, - dažni [8]. Timoma yra diagnozuojama $10 \%$ sergančiųjų, kitais duomenimis, net $15-20 \%$ atvejų. $80 \%$ likusių pacientų pooperacinès medžiagos histologinio tyrimo metu nustatoma limfoidinių folikulų hiperplazija su aktyviais germinatyviniais centrais $[9,10]$. Antikūnai, kurių gamyba indukuojama užkrūčio liaukos patologijos, kryžmiškai jungiasi prie AchR, blokuoja jų veikimą, o

(C) Neurologijos seminarai, 2020. Open Access. This article is distributed under the terms of the Creative Commons Attribution 4.0 International License CC-BY 4.0 (http://creativecommons.org/licenses/by/4.0/), which permits unrestricted use, distribution, and reproduction in any medium, provided you give appropriate credit to the original author(s) and the source, provide a link to the Creative Commons license, and indicate if changes were made. 
prisijungus komplementui, dėl imuninio uždegimo įvyksta AchR destrukcija, pakinta sinapsès struktūra (mažeja receptorių, platėja sinapsinis plyšys) $[3,11]$.

Miastenija su anti-MuSK serga 2,9 asmens iš milijono, per metus registruojama 0,3 atvejo milijonui gyventojų. Miastenija su anti-LRP4 sudaro tik maždaug pusę antiMuSK miastenijos atvejų $[11,12]$.

Sergant miastenija, pažeista sinapsè ne visada praleidžia nervinį impulsą ir, jei tokių sinapsių raumenyje atsiranda daug, pastebime miastenijos simptomus: raumenų silpnumą ir patologinị nuovargi, kuris pasireiškia praeinančiais paralyžiais.

\section{MIASTENIJOS KLINIKA IR DIAGNOSTIKA}

Dažniausiai miastenija prasideda akių simptomais - tai asimetriška ptozè, dvejinimasis, akių judesių sutrikimas iki oftalmoplegijos. Akių simptomai stebimi $60 \%$ pacientų, o $20 \%$ visų sergančiųjų liga pasireiškia tik ptoze ir dvejinimusi, t. y. akių miastenija. Orofaringinių raumenų silpnumas prasideda kiek vẻliau ligos eigoje - kliniškai stebime rijimo sutrikimus, dizartriją, disfoniją. Griaučių raumenų nusilpimas yra dar vėlesnis požymis, proksimaliniai raumenys nukenčia labiau negu distaliniai, o rankų - labiau negu kojų. Tipiškas miastenijos požymis yra silpnumo padidejjimas fizinio krūvio metu, o pailsejjus jèga pagerèja. Pavyzdžiui, kalbant balsas pradeda duslèti, kol visai išnyksta.

Simptomai apsiriboja motorine sistema, jutimų sutrikimų, skausmų, sausgyslių refleksų pakitimų, autonominès nervų sistemos pažeidimo požymių nebūna. Taip pat nẻ vienas iš trijų pagrindinių antikūnų nereaguoja su širdies raumeniu, nors yra stebėta širdies pažeidimo simptomų miozitas, laidumo sutrikimai $[3,11]$.

Miastenija diagnozuojama pagal simptomus ir požymius, atlikus ritminę stimuliaciją ir patvirtinus laidumo sutrikimą neuroraumenineje jungtyje (nustatomas dekrementas $>8-10 \%$, tai - raumens atsako sumažejimas, stimuliuojant nervą impulsų serija), bei nustačius antikūnų prieš AchR kraujo serume (80-90 \% atvejų), rečiau - prieš MuSK ir labai retai - anti-LRP4, jei yra galimybių juos ištirti. Visiems pacientams atliekama krūtinès ląstos kompiuterinè tomografija, ieškant timomos [3].

Miastenija skirstoma pagal sunkumą (senoji, iki šiol taikoma klasifikacija pagal Osserman), o gydymo taktikai pasirinkti padeda jos suskirstymas ị potipius. Skiriami šie skirtingos eigos variantai [11]:

1) Ankstyvos pradžios miastenija su antikūnais prieš AchR. Susergama iki 50 m. amžiaus, šioje grupejje vyrauja moterys, moterų ir vyrų santykis - 3:1. Histologiškai dažna čiobrialiaukès folikulų hiperplazija, timektomijos rezultatai būna geri [2].

2) Vèlyvos pradžios miastenija su antikūnais prieš AchR. Susergama po $50 \mathrm{~m}$. amžiaus. Užkrūčio liaukos hiperplazija diagnozuojama retai, timektomija nepagerina ligos eigos.
3) Miastenija, susijusi su timoma. Šiuo atveju tai - paraneoplazinis susirgimas. Beveik visada nustatomi antikūnai prieš AchR, o pacientams su timoma, bet be miastenijos simptomų, taip pat gali būti nustatomi anti-AchR.

4) Miastenija su antikūnais prieš MuSK. Suserga suaugę asmenys, labai retai - vaikai. Čiobrialiaukès pokyčių nenustatoma, timektomija šiems pacientams - neefektyvi. Pagrindiniai simptomai, sergant miastenija su anti-MuSK, yra galvos ir orofaringinių raumenų silpnumas, nuo jo liga ir prasideda. Labai tipiškas požymis - liežuvio pažeidimas. Silpnumo svyravimai dieną būna nežymūs, galimos raumenų atrofijos [12].

5) Miastenija, susijusi su antikūnais prieš LRP4. Kliniškai stebimas akių raumenų silpnumas, lengvas griaučių raumenų silpnumas. Užkrūčio liaukos pakitimai atitinka amžinius.

6) Miastenija be nustatytų antikūnų. Tai pagal klinikinę išraišką - heterogeninė grupè. Visada reikètų svarstyti kitų raumeninių ar ne raumeninių susirgimų galimybę.

7) Akių miastenija. Šios grupès pacientams stebimas tik akių raumenų silpnumas, tačiau anksti ligos eigoje yra generalizacijos tikimybè.

\section{MIASTENIJOS GYDYMAS}

Miastenijos gydymas skiriamas ị simptominị ir patogenetinic. Simptomus palengvina acetilcholinesterazès inhibitoriai, pagrindinis jų - piridostigmino bromidas („Mestinon“, „Kalimin“). Jo pradinė dozė yra $60 \mathrm{mg} 4$ kartus per parą, ją galima didinti iki $1500 \mathrm{mg}$ suminès dozès. Acetilcholinesterazès inhibitoriai padidina acetilcholino kiekị sinapsiniame plyšyje $[10,11,13]$. Jie yra mažiau efektyvūs, sergant anti-MuSK miastenija [12]. Vartojant didesnes dozes, būna šalutinių reiškinių dẻl padidejjusio acetilcholino kiekio, kuris pasiekia muskarininius ir nikotininius receptorius. Tai - žarnyno hipermobilumas (viduriavimas, pilvo skausmai), padidèjęs prakaitavimas, padidèjusi sekrecija žarnyne ir bronchuose, bradikardija, fascikuliacijos, mėšlungiai. Šalutiniams reiškiniams mažinti siūloma atropino, loperamido. Gydymą acetilcholinesterazès inhibitoriais galima saugiai tęsti neribotą laiką. Šių vaistų gali užtekti, jei simptomai yra lengvi $[11,13]$. Nors vaistų poveikis akivaizdus, pagal formalius reikalavimus, ịrodymai tėra IV klasès - tai geros praktikos nuoroda [13].

Patogenetinis miastenijos gydymas - imunosupresija. Jis skiriamas visada, kai nepakankamai pagerèja, taikant acetilcholinesterazès inhibitorius. Pradedama nuo gliukokortikoidų, plačiausiai skiriamas prednizolonas, rečiau metilprednizolonas. Sunkesniais atvejais pradedama nuo 0,75-1 mg/kg per dieną, t. y. 60-80 mg per parą, o mažinama pasiekus remisiją maždaug po 4-16 savaičių iki mažiausios efektyvios. Pagerejja per 2-6 savaites. Kartais siūloma taikyti prednizoloną kas antrą dieną, siekiant sumažinti šalutinius reiškinius, tačiau toks dozavimo režimas netinka sergantiesiems cukralige (sunkiai kontroliuojami glikemijos svyravimai), be to, dienomis be vaisto raumenu jèga gali būti gerokai silpnesnè. Tokiomis dienomis siūlo- 
ma skirti mažą prednizolono dozę (5-10 mg). Jei prognozuojama, kad reikès ilgalaikès imunosupresijos arba šalutiniai prednizolono reiškiniai yra ryškūs, o palaikomoji dozè - didelé, pridedama azatioprino $2-3 \mathrm{mg} / \mathrm{kg}$ per parą. Tokia gydymo schema pagal ịrodymus gali būti pateikta kaip A lygio rekomendacija [13]. Steroidus taupantis azatioprino efektas tikètinas po 3-12 mèn. Gliukokortikoidu ir azatioprino derinys yra efektyvus beveik visiems sergantiems miastenija [11].

Be azatioprino, imunosupresijai naudojami metotreksatas, ciklofosfamidas, ciklosporinas, mikofenolio mofetilis (Lietuvoje miastenijai gydyti neregistruoti), retai - kiti. Šiuos vaistus galima rinktis, jei pirmo pasirinkimo imunosupresantai yra neefektyvūs. Metotreksatas neturi įrodymų miastenijos atveju, ciklosporinas - labai toksiškas, o ciklofosfamidas skirtinas, tik jei netoleruojami visi kiti vaistai - B lygio rekomendacija [13]. Mikofenolato mofetilis mažai ištirtas sergant miastenija $[10,11,13]$. Sunkiais atvejais, kai gydymas ịprastiniais imunosupresantais būna neefektyvus, skiriama rituksimabo [14]. Svarstoma, kad rituksimabą galima būtų rekomenduoti pasirinkimui kaip antros eilès vaistą imunosupresijai, tačiau neužtenka ịrodymų [11]. Jis kelių atvirų ir nekontroliuojamų tyrimų metu buvo efektyvus, gydant anti-MuSK miasteniją, kas yra svarbu, nes būtent šiems pacientams neretai nepagerèja skiriant pirmos eilès vaistus $[11,15]$.

Kadangi viena pagrindinių miastenijos patogenetinių grandžių yra užkrūčio liaukos patologija, timektomija buvo pradèta taikyti kaip vienas gydymo metodų. Atliktų tyrimų duomenimis, tarp pacientų po timektomijos dažnesnès būna remisijos, retesni pablogèjimai, jų ilgalaikè prognozė geresnè. Atlikus timektomiją, pasiekiama geresnių rezultatų, nei taikant tik konservatyvius gydymo metodus, kaip acetilcholinesterazės inhibitorius, imunosupresantus ar gydomąsias aferezes [16]. Timektomija, siekiant geresnės miastenijos simptomų kontrolès, mažesnių vaistų dozių rekomenduojama visiems, jei nustatoma timoma, ir jaunesniems, jei yra generalizuota miastenija su antikūnais prieš AchR. Ji turètų būti atlikta stabilizavus paciento būklę, remiantis miastenijos patogeneze - labai ilgai nelaukiant. Miastenijos su antikūnais prieš MuSK atveju timektomijos vertė nepatvirtinta, ji neturètų būti rekomenduojama. Amžiaus riba, iki kurios rekomenduojama atlikti timektomiją, kito, šiuo metu tai - 60 m., vyresniems jos nauda yra abejotina $[13,17]$.

Refrakterinės miastenijos atveju tiriami nauji vaistai ekulizumabas, efgartigimodas. Naujausios tyrimu kryptys - paieškos veiksmingų medžiagų, kurios moduliuotų AchR antikūnus, veiktų B limfocitus, indukuotų imuninę toleranciją, veiktų mikroRNR ir igimtą imunitetą [18].

\section{MIASTENINE் KRIZE் IR JOS GYDYMAS}

Sergant miastenija, galimi ryškūs pablogejjimai, kai raumenų silpnumas pradeda greitai (per kelias dienas ar savaites) didèti. Kliniškai stebima nusvirusi galva, išsekantis ir (ar) nesuprantamas balsas, apsunkintas rijimas, pacientas sunkiai pakelia rankas, nepaeina, paviršutiniškai kvėpuoja. Miastenijos pablogèjimas, kai pacientas nebegali be mechaninès pagalbos nuryti ir (ar) kvèpuoti, vadinamas miastenine krize (MK).

Krizès ir pablogėjimai labiausiai tikètini per pirmuosius metus nuo susirgimo pradžios. $70 \%$ pacientų sunkūs pablogèjimai ištinka per pirmus sirgimo metus, o per trejus $-85 \%$ visų pacientų. Jų priežastys pirmiausia yra nepakankamas gydymas - $41 \%$ atvejų, gydymo režimo nesilaikymas - $23 \%$ atvejų, infekcijos - dar $23 \%$ atvejų ir šalutinis vaistų poveikis - $13 \%$. Krizès ištinka 15-20\% sergančiujų miastenija, dauguma atvejų diagnozuojami per pirmuosius dvejus metus. Mirštamumas, ištikus MK, iki šiol siekia 3-8 \%. MK rizikos veiksniai yra didesnis nei $40 \mathrm{~m}$. paciento amžius, trumpa sunkios ligos anamnezè, timoma [19].

Kvėpavimo nepakankamumas MK metu vystosi dėl diafragmos ir pagalbinių kvėpuojamųjų raumenų silpnumo. Dirbtinès plaučių ventiliacijos taip pat gali prireikti dèl orofaringinių raumenų silpnumo, stridoro dèl balso klosčių parezès, hipersekrecijos [20].

Gydomosios aferezès - pasirinkimo metodas (ekspertu nuomone), esant MK ir sunkiam pablogejjimui (gresiančiai krizei). Vis tik reikalaujamų ịrodymų šis metodas neturi pakankamai [21]. Atliekamos 5-6 pakaitinès gydomosios aferezės kas dieną arba kas antrą dieną, pakeičiant per 1 seansą 2-4 1 kraujo. Taip pat galima taikyti dvigubos filtracijos aferezes, imunoadsorbciją. Intraveninių imunoglobulinų (IVIg) infuzijos taip pat skiriamos esant MK, dozė yra $0,4 \mathrm{~g} / \mathrm{kg}$ per 3-5 dienas (iš viso iki $2 \mathrm{~g} / \mathrm{kg}$ svorio) [22]. Savo efektyvumu jos yra lygiavertės gydomosioms aferezėms, tik pagerèjimo sulaukiama kiek vèliau [10, 13]. Gydymo IVIg privalumas - mažesni šalutiniai reiškiniai. Nèra pakankamai duomenų, įrodančių IVIg arba gydomųjų aferezių pranašumą, bet vis tik yra tyrimų, kurie leidžia manyti, kad, esant sunkiai krizei, gydomosios aferezès - pranašesnès [23].

Esant MK arba sunkiam pablogėjimui (gresianti krizè), reikia keisti gliukokortikoidų dozę. Problema - gliukokortikoidai sukelia raumenų silpnumo padidejjimą 4-10 dieną po paskyrimo. Rekomenduojama pradèti gydymą 10-25 mg prednizolono dozę didinant kas antrą dieną po $10 \mathrm{mg}$ iki $60-80 \mathrm{mg}$, o jei būklè sunki arba jau pradèta dirbtinè plaučių ventiliacija, iškart skiriama $60-80 \mathrm{mg}$ prednizolono. Jei pacientas jau ilgai vartojo prednizolono, dozè didinama iki 60-80 mg. Galima skirti metilprednizolono 60 mg kas 6-8 val. ị veną, jei taikoma DPV arba netoleruojami geriamieji vaistai [19].

IVIg ir pakaitinès gydomosios aferezès, nors pagrindinẻ jų indikacija yra ryškus MG pablogejjimas ir MK, gali būti bandomos sunkios miastenijos atvejais ir nesant ryškaus pablogejjimo, kai geriamieji vaistai yra nepakankamai efektyvūs arba esama sunkių jų šalutinių reiškinių. Problema - pagerèjimai būna trumpalaikiai [21]. Pacientai, sergantys akių miastenija ir lengva generalizuota miastenija, po IVIg infuzijos dažniausiai nepagereja. Taip pat gydomosios aferezès rekomenduojamos ruošiant pacientą timektomijai $[10,13]$. 
Kaip skirti acetilcholinesterezès inhibitorius, esant MK, bendro sutarimo nèra. Jei pacientas nevartojo acetilcholinesterazès inhibitorių, skiriama $1 \mathrm{ml}$ syntostigmino tirpalo $(0,5 \mathrm{mg}$ neostigmino) ì veną arba ị raumenis po 0,5-2,5 mg kas 1 valandą, maksimali paros dozè - $10 \mathrm{mg}$. Jei pacientas vartojo acetilcholinesterazès inhibitorių, galimas jų perdozavimas. Jis tikètinas, jei viršyta 16 tablečiu piridostigmino per parą dozė ir kartu su silpnumu yra išreikšti cholinerginiai reiškiniai, vadinamojo SLUDGE (angl. salivation, lacrimation, urination, defecation, gastrointestinal distress, emesis) sindromo požymiai (seilètekis, ašarojimas, šlapimo nelaikymas, žarnyno hipermobilumas, vėmimas). Dauguma ekspertų pasisako už tai, kad, pradèjus dirbtinę plaučių ventiliaciją (DPV), acetilcholinesterazès inhibitorius reikia nutraukti 48-72 valandoms $[13,19]$.

\section{LAMBERT-EATON MIASTENINIS SINDROMAS}

Lambert-Eaton miasteninio sindromo (LEMS) atveju nustatomi antikūnai prieš presinapsinius su ịtampa susijusius kalcio kanalus (angl. voltage gated calcium channels, anti-VGCC), dẻl ko sumažeja acetilcholino patekimas ị sinapsini plyšį [5]. Tai - retas susirgimas, miastenija yra 46 kartus dažnesnè nei LEMS. Jis daug dažniau diagnozuojamas vyrams, kurie sudaro 60-75\% sergančiujų. $60 \%$ atvejų jis yra susijęs su smulkialąsteliniu plaučių vėžiu, nors jauniems asmenims ši sąsaja - retesnè. Dẻl savo dažnos sąsajos su vẻžiu, LEMS yra skirstomas į paraneoplastinị ir idiopatinį. Vidutinis susirgimo neparaneoplastiniu LEMS amžius yra 35 m., kai paraneoplastiniu - 58 m. [24].

\section{LEMS KLINIKA IR DIAGNOSTIKA}

Lambert-Eaton miasteninio sindromo klinika yra panaši ị miastenijos, taip pat stebimas patologinis raumenų nuovargis, raumenų silpnumas be atrofijų, tačiau labiausiai nusilpusių raumenų pasiskirstymas yra kitoks. Vèlgi proksimaliniai raumenys nukenčia labiau nei distaliniai, tačiau, skirtingai nuo miastenijos, pirmiausia nusilpsta ne rankų, o kojų raumenys. Akių ir orofaringiniai raumenys pažeidžiami tik jau pažengus ligai, gerokai rečiau, nei sergant MG [25]. Skirtingai nuo miastenijos, po krūvio galimas labai trumpalaikis jègos pagerèjimas. Sausgyslių refleksai pažemejja, jie gali pagyvèti po krūvio. Pacientai jaučia mialgijas, būna cholinerginès disautonomijos požymių: sausa burna, sumažèjęs prakaitavimas, posturalinė hipotenzija, impotencija [25]. Labai tikètina, kad LEMS yra nepakankamai diagnozuojamas, ypač tarp sergančiųjų plaučių smulkialąsteliniu vėžiu, nes simptomai aiškinami nusilpimu dèl vėžinio proceso ar vaistų, skiriamų vėžiui gydyti, šalutiniu poveikiu.

LEMS diagnozuojamas pagal klinikinius požymius. Tai - tipiška triada: proksimalinių raumenų silpnumas, pažemėję sausgyslių refleksai ir autonominè disfunkcija
[26]. Diagnozę patvirtina ritminè nervo stimuliacija, kurios metu nustatomas posinapsinio tipo laidumo sutrikimas neuroraumeninèje jungtyje (žemi raumens atsakai, stimuliuojant nervą, dekrementas $>8-10 \%$ - raumens atsako sumažejjimas, stimuliuojant nervą impulsų serija, tačiau atsakai padidèja, o dekrementas išnyksta po krūvio arba stimuliuojant nervą didelio dažnio impulsų serija) [3, 27]. Antikūnų, anti-VGCC, radimas kraujo serume yra labai svarbus diagnostinis kriterijus, nes jie nustatomi net $85 \%$ LEMS atvejų [28].

\section{LEMS GYDYMAS}

LEMS gydomas pagal tuos pačius principus, kaip ir miastenija, vaistai skiriami siekiant pagerinti nervinio impulso perdavimą neuroraumenineje jungtyje - tai simptominis gydymas, o patogenetiniam gydymui, nepakankant simptominio, reikalingi imunomoduliuojantys vaistai [3]. Laidumą sinapseje, sergant LEMS, pagerina piridostigminas, guanidinas, 4-aminopiridinas, 3,4-diaminopiridinas (3,4-DAP). Efektyviausias jų - 3,4-DAP (Lietuvoje neregistruotas). Jo molekulès prisijungia prie nuo įtampos priklausančių kalcio kanalų, jie ilgiau lieka atviri [29]. 2009 m. 3,4-DAP patvirtintas Europoje LEMS gydyti, o nuo $2010 \mathrm{~m}$. rekomenduojamas kaip pirmo pasirinkimo vaistas simptominiam LEMS gydymui [30]. Naujausias vaistas - amifampridinas („Firdapse“) yra 3,4-DAP druska, gydyti juo pradedama nuo 15-30 mg 3 kartus per dieną.

Guanidinas taip pat gerina laidumą neuroraumeninèje jungtyje, jis padidina acetilcholino išsiskyrimą ị sinapsinị plyši. Skiriamas ribotai, kadangi yra daug šalutinių reiškinių, tačiau tinka monoterapijai arba kartu su piridostigminu, jei netoleruojamas amifampridinas arba jo nèra. Rekomenduojamos dozès - iki 1000 mg per dieną.

Piridostigminas yra geriausiai toleruojamas iš visų acetilcholinesterazės inhibitorių. Jis taip pat rekomenduojamas simptominiam LEMS gydymui, dozė priklauso nuo efekto - nuo 30 iki $180 \mathrm{mg}$ per dieną [31].

Jei simptominis gydymas nepakankamai efektyvus, o taip būna dažniausiai, pradedamas imunomoduliuojantis gydymas. Skiriama gliukokortikoidų, iprastai prednizolono, vartojimo schema ta pati, kaip sergant miastenija: pradedama nuo 1-1,5 mg/kg per dieną ir mažinama, pagerẻjus paciento būklei. Taip pat gali būti skirta azatioprino: pradedant nuo $50 \mathrm{mg}$ du kartus per dieną ir didinant iki $2-3 \mathrm{mg} / \mathrm{kg}$ dienos dozès $[3,31]$. Šie abu vaistai ịprastai vartojami Lietuvoje, kitose šalyse yra skiriama ir mikofenaloto mofetilio bei ciklosporino.

Intraveniniai imunoglobulinai standartinèmis dozèmis rekomenduojami LEMS gydyti kaip pirmo pasirinkimo vaistas, jei jëga negerèja, tačiau jų efektas yra trumpalaikis $[13,31]$.

Gydomosios aferezès gali būti skiriamos kartu su kitu imunosupresiniu gydymu, jei nepavyksta pasiekti pakankamo simptomų pagerẻjimo. Vèlgi rekomenduojama ta pati schema, kaip ir gydant miasteniją - 5 pakaitinès gydomosios aferezès [3]. 
Jei kiti imunosupresantai - neefektyvūs, skiriama rituksimabo $375 \mathrm{mg} / \mathrm{m}^{2}$ kartą per savaitę 4 savaites, po to kartą per mènesi kitus du mènesius [14].

Tumoro pašalinimas, jei jis diagnozuotas, pagerina ligos simptomus [31].

\section{PACIENTŲ, SERGANČIŲ MIASTENIJA IR LEMS, PRIEŽIŪROS REKOMENDACIJOS COVID-19 PANDEMIJOS METU}

\section{Bendra informacija}

Koronaviruso liga 2019 (COVID-19) - naujojo koronaviruso sukeltas susirgimas, pažeidžiantis viršutinius kvėpavimo takus ir plaučius. Ligai būdingas karščiavimas, kosulys, dusulys, plaučių uždegimas, viduriavimas, skonio ir kvapų jutimų sutrikimai. Daliai pacientų naujasis virusas gali sukelti ūmų respiracinio distreso sindromą, pagal tai šis virusas ir pavadintas 2-uoju kororavirusu, kuris sukelia ūmų sunkų respiracinio distreso sindromą (angl. severe acute respiratory distress syndrome coronavirus 2, SARS-CoV-2). Virusas yra išplitęs beveik visose pasaulio šalyse, o specifinis gydymas šiuo metu dar nėra patvirtintas.

Nèra pakankamai duomenų, kaip COVID-19 infekcija veikia neuroraumeninių ligų eigą ir kaip neuroraumeninès ligos bei jų gydymas gali turèti įtakos imlumui SARS-CoV-2. Remiantis Pasaulio raumenų asociacijos (angl. World Muscle Society) pozicija, ì didelès rizikos grupę susirgti sunkiu COVID-19 patenka pacientai, sergantys neuroraumeninėmis ligomis, jei:

1) diagnozuotas kvėpavimo raumenų silpnumas ir forsuota iškvėpimo gyvybinė plaučių talpa (angl. forced vital capacity, FVC) yra $<60 \%$;

2) diagnozuotas orofaringinių raumenų silpnumas;

3) pradèta dirbtinè plaučių ventiliacija ar taikomos pagalbinès kvėpavimo priemonės;

4) pažeistas širdies raumuo;

5) diagnozuotos neuroraumeninès jungties ligos, kurių eigą gali pabloginti infekcija;

6) kartu sergama cukriniu diabetu, nutukimu;

7) gydoma gliukokortikoidais ar imunosupresantais.

Neuroraumeninių ligų priežiūros taktika pandemijos metu skirtingose šalyse varijuoja. Toliau pateikiamos MG/LEMS gydymo gairès, remiantis apibendrintomis $\mathrm{Pa}-$ saulio raumenų asociacijos, Tarptautinès MG/LEMS darbo grupès ir Britų neurologų asociacijos parengtomis rekomendacijomis [32-34].

\section{Pacientai, kuriems skiriamas simptominis ir imunoterapinis miastenijos ar LEMS gydymas}

1. Nèra įrodymų, kad acetilcholinesterazès inhibitorius piridostigminas ir 3,4-DAP didintų COVID-19 infekcijos riziką, todèl gydymas šiais vaistais turètų būti tęsiamas, jei neatsiranda kitų kontraindikacijų.

2. Pacientai, vartojantys didesnes nei $20 \mathrm{mg}$ prednizolono dozes per parą, priskiriami didelès COVID-19 infekci- jos rizikos grupei, tačiau, esant aktyviai ligai, vaisto nutraukti nerekomenduojama, nes vertinama, kad paūméjimo rizika - didesnè.

3. Pacientams, vartojantiems azatioprino, mikofenolato mofetilio, metotreksato su (be) prednizolonu, gydymas turètų būti tęsiamas. Nors ir trūksta duomenų, ar šiu vaistų vartojimas didina užsikrètimo naujuoju koronavirusu ir jo komplikacijų tikimybę, manoma, kad rizika nèra didesnè nei vaisto nauda, slopinant autoimuninio proceso aktyvumą.

4. Rituksimabo ar okrelizumabo skyrimas didina imlumą virusinėms infekcijoms, tačiau daugeliu atvejų šis alternatyvus gydymas skiriamas sunkioms, refrakterinėms miastenijos ar LEMS formoms gydyti. Remiantis ekspertų rekomendacijomis, gydymas galètų būti tęsiamas, jei nėra kitų alternatyvų ir vaisto nauda viršija riziką.

\section{Miastenijos ir LEMS gydymas gydomosiomis aferezėmis ir intraveniniais imunoglobulinais}

1. Šiuo metu nėra aiškių įrodymų, kad gydymas gydomosiomis aferezėmis ar IVIg padidina užsikrètimo naujuoju virusu riziką. Indikacijos gydymui turi būti ịvertintos individualiai, siekiant išvengti nebūtinų procedūrų skyrimo.

2. Kadangi, taikant IVIg infuzijas ir gydomąsias aferezes, reikalingas reguliarus atvykimas ị ligoninę ar hospitalizacija, rekomenduojama individualiai icvertinti regioninị COVID-19 paplitimą ir procedūrų tikslingumą, naudos ir rizikos santykị. Jei yra galimybè, rekomenduojama skirti poodines IVIg formas.

3. Gydomosios aferezès ar IVIg turi būti skiriami tik sunkaus ligos pablogéjimo metu, esant miasteninei krizei, ar greitai progresuojant ligos simptomams, kai iškyla miasteninès krizès grèsmè.

4. Tais atvejais, kai gydomosios aferezès ar IVIg infuzijos skiriamos periodiškai kaip palaikomasis gydymas jis turètų būti tęsiamas, siekiant išvengti ligos pablogèjimo.

\section{Kontrolinių kraujo tyrimų atlikimas pacientams, gydomiems imunoterapija}

Būtini kontroliniai kraujo tyrimai turi būti atliekami imunosupresinị gydymą gaunantiems pacientams ir pandemijos metu. Kraujas tyrimams turi būti paimtas kiek įmanoma sumažinant tiesioginių kontaktų su gydymo įstaigos personalu skaičių. Visus tyrimus reikètų paimti vieno apsilankymo metu, rezultatai pranešami nuotoliniu būdu. Jei yra galimybè, kraujo mėginiai tyrimui gali būti paimti namuose.

\section{Kada pradèti imunoterapini gydymą miastenija ir LEMS sergantiems pacientams?}

Esant aktyviai miastenijai ar LEMS, gydymą piridostigmi$\mathrm{nu}, 3,4-\mathrm{DAP}$, prednizolonu, azatioprinu rekomenduojama 
pradėti įprasta tvarka, siekiant išvengti ligos simptomų blogejjimo.

Jei epidemijos metu planuojama skirti B limfocitų skaičių mažinančius vaistus (rituksimabo, okrelizumabo), rekomenduojama įvertinti ligos blogejjimo ir užsikrètimo naujuoju virusu riziką. Jei ịmanoma, rekomenduojama atidèti imunoterapini gydymą bent jau iki pandemijos piko pabaigos regione.

\section{Miastenija ir LEMS sergančių pacientų priežiūra, užsikrètus COVID-19}

1. Daugumai COVID-19 infekuotų pacientų pasireiškia lengvi simptomai, todėl imunoterapinis gydymas turètų būti tęsiamas.

2. Jei infekcijos fone miastenijos simptomai pablogèja, o infekcijos simptomai yra lengvi, gliukokortikoidų dozè gali būti didinama.

3. Esant sunkiai infekcijai (pneumonijai, sepsiui), imunosupresini gydymą rekomenduojama nutraukti, paliekant tik simptomini gydymą.

4. Svarbu atkreipti demesi, kad šiuo metu COVID-19 infekcijai gydyti taikomi vaistai - hidroksichlorokvinas, azitromicinas, kai kurie antivirusiniai preparatai - gali bloginti miastenijos simptomus, todèl, prieš skiriant gydymą, būtina atidžiai įvertinti naudos ir rizikos santyki. Jeigu gydymas šiais vaistais yra būtinas, reikia nuosekliai stebėti neurologinę pacientų būklę, užtikrinant dirbtinės plaučių ventiliacijos prieinamumą, ligai pablogèjus.

\section{IŠVADOS}

Pacientai, sergantys neuroraumeninėmis ligomis, gali turèti kvẻpuojamujų ir orofaringinių raumenų silpnumą, naudoti palaikomąsias priemones kvėpavimui ar jiems net gali būti taikoma dirbtinè plaučių ventiliacija. Tad šie pacientai priklauso COVID-19 rizikos grupei. Neuroraumeninių ligų gydymą pandemijos metu rekomenduojama pradèti ir tęsti pagal bendras rekomendacijas. Jei pacientams skirta imunosupresantų, šis gydymas turètų būti tęsiamas, nes nauda yra didesnè už galimą žalą.

\section{Literatura}

1. McGrogan A, Sneddon S, de Vries CS. The incidence of myasthenia gravis: a systematic literature review. Neuroepidemiology 2010; 34(3): 171-83. https://doi.org/10.1159/ 000279334

2. Heldal AT, Owe JF, Gilhus NE, et al. Seropositive myasthenia gravis: a nationwide epidemiologic study. Neurology 2009; 73: 150-1. https://doi.org/10.1212/WNL. 0b013e3181ad53c2

3. Nicolle MW. Myasthenia gravis and Lambert-Eaton myasthenic syndrome. Continuum 2016; 6: 1978-2005. https://doi.org/10.1212/CON.0000000000000415

4. Younger DS, Worrall BB, Penn AS. Myasthenia gravis: historical perspective and overview. Neurology 1997;
48(Suppl 5): S1-7. https://doi.org/10.1212/WNL. 48.Suppl_5.1S

5. Lennon VA. Serologic profile of myasthenia gravis and distinction from the Lambert-Eaton myasthenic syndrome. Neurology 1997; 48(Suppl 5): 23-7. https://doi.org/ 10.1212/WNL.48.Suppl_5.23S

6. Hoch W, McConville J, Helms S, Newsom-Davis J, et al. Auto-antibodies to the receptor tyrosine kinase MuSK in patients with myasthenia gravis without acetylcholine receptor antibodies. Ant Med 2001; 7: 365-8. https://doi.org/ $10.1038 / 85520$

7. Berrih-Aknin S, Frenkian-Cuvelier M, Eymard B. Diagnostic and clinical classification of autoimmune myasthenia gravis. Autoimmunity 2014; 48-49: 143-8. https://doi.org/ 10.1016/j.jaut.2014.01.003

8. Le Panse R, Bismuth J, Cizeron-Clairac G, Weiss JM, et al. Thymic remodeling associated with hyperplasia in myasthenia gravis. Autoimmunity 2010; 43: 401-12. https://doi.org/ 10.3109/08916930903563491

9. Marx A, Pfister F, Schalke B, Saruhan-Direskeneh G, Meims A, Strobel P. The different roles of the thymus in the pathogenesis of the various myasthenia gravis subtypes. Autoimmun Rev 2013; 12: 875-84. https://doi.org/10.1016/ j.autrev.2013.03.007

10. Silvestri NJ, Wolfe GI. Myasthenia gravis. Semin Neurol 2012; 32: 215-26. https://doi.org/10.1055/s-0032-1329200

11. Gilhus NE, Verschuuren JJ. Myasthenia gravis: subgroup classification and therapeutic strategies. Lancet Neurol 2015; 14: 1023-36. https://doi.org/10.1016/S14744422(15)00145-3

12. Guptill J, Sanders DB, Evoli A. Anti-MuSK antibody myasthenia gravis: clinical findings and response to treatment in two large cohorts. Muscle Nerve 2011; 44: 36-40. https://doi.org/10.1002/mus.22006

13. Skeie GO, Apostolski S, Evoli A, Gilhus N, et al; European Federation of Neurological Societies. Guidelines for treatment of autoimmune neuromuscular transmission disorders. Eur J Neurology 2010; 17(7): 893-902. https://doi.org/ 10.1111/j.1468-1331.2010.03019.x

14. Maddison P, McConville J, Farrugia MA, et al. The use of rituximab in myasthenia gravis and Lambert-Eaton myasthenic syndrome. J Neurol Neurosurg Psychiatry 2011; 82: 671-3. https://doi.org/10.1136/jnnp.2009.197632

15. Keung B, Robeson KR, DiCapua DB, et al. Long-term benefit of rituximab in MuSK autoantibody myasthenia gravis patients. J Neurol Neurosurg Psychiatry 2013; 84: 1407-9. https://doi.org/10.1136/jnnp-2012-303664

16. Rashid MH, Yasir HK, Piracha MU, et al. Review analysis on thymectomy vs conservative medical management in myasthenia gravis. Cureus 2020; 12(3): e7425. https://doi.org/ $10.7759 /$ cureus. 7425

17. Gronseth GS, Baron RJ. Thymectomy in myasthenia gravis. Neurology 2000; 55: 7-15. https://doi.org/10.1212/ WNL.55.1.7

18. Mantegazza R, Bernasconi P, Cavalcante P. Myasthenia gravis: from autoantibodies to therapy. Curr Opin Neurol 2018; 31: 517-25. https://doi.org/10.1097/WCO. 0000000000000596

19. Jani-Ascadi A, Lisak RP. Myasthenic crisis: guidelines for prevention and treatment. J Neurol Sci 2007; (261): 127-33. https://doi.org/10.1016/j.jns.2007.04.045

20. Damian MS, Wijdicks EF. The clinical management of neuromuscular disorders in intensive care. Neuromuscul 
Disord 2019; 29: 85-96. https://doi.org/10.1016/j.nmd. 2018.12.005

21. Gajdos P, Chevret S, Toyka K. Plasma exchange for myasthenia gravis. Cochrane Database Syst Rev 2002; (4): CD002275. https://doi.org/10.1002/14651858. CD002275

22. Gajdos $P$, Chevret $S$, Toyka K. Intravenous immunoglobulin for myasthenia gravis. Cochrane Database Syst Rev 2008; (1): CD002277. https://doi.org/10.1002/14651858. CD002277.pub3

23. Barth D, Nabavi Nouri M, Ng E, et al. Comparison of IVIg and PLEX in patients with myasthenia gravis. Neurology 2011; 76(23): 2017-23. https://doi.org/10.1212/WNL. 0b013e31821e 5505

24. Elrington GM, Murray NM, Spiro SG, Newsom-Davis J. Neurological paraneoplastic syndromes in patients with small cell lung cancer. A prospective survey of 150 patients. J Neurol Neurosurg Psychiatry 1991; 54: 764-7. https://doi.org/10.1136/jnnp.54.9.764

25. Titulaer MJ, Wirtz PW, Kuks JB, et al. The Lambert-Eaton myasthenic syndrome 1988-2008: a clinical picture in $97 \mathrm{pa}-$ tients. J Neuroimmunol 2008; 15: 153-8. https://doi.org/ 10.1016/j.jneuroim.2008.05.025

26. Titulaer MJ, Lang B, Verschuuren JJ. Lambert-Eaton myasthenic syndrome: from clinical characteristics to therapeutic strategies. Lancet Neurol 2011; 10: 1098-107. https://doi.org/10.1016/S1474-4422(11)70245-9

27. Chiou-Tan FY, Tim RW, Gilchrist JM, et al. Practice parameter for repetitive nerve stimulation and single fiber EMG evaluation of adults with suspected myasthenia gravis or Lambert-Eaton myasthenic syndrome: summary statement. Muscle Nerve 2001; 1: 1236-8.

28. Gilhus NE. Lambert-Eaton myasthenic syndrome; pathogenesis, diagnosis, and therapy. Autoimmune Dis 2011; 2011: 973808. https://doi.org/10.4061/2011/973808

29. Sanders DB, Juel VC, Harati Y, et al. 3,4-diaminopyridine base effectively treats the weakness of Lambert-Eaton myasthenia. Muscle Nerve 2018; 57: 561-8. https://doi.org/ $10.1002 /$ mus. 26052

30. Kesner VG, Oh SJ, Dimachkie MM, Baron RJ. LambertEaton myasthenic syndrome. Neurol Clin 2018; 36: 379-94. https://doi.org/10.1016/j.ncl.2018.01.008

31. Anwar A, Saleem S, Ahmed M, et al. Recent advances and therapeutic options in Lambert-Eaton myasthenic syndrome. Cureus 2019; 11(8): e5450. https://doi.org/10.7759/ cureus. 5450

32. Covid-19 and people with neuromuscular disorders: World Muscle Society position and advice. April 20th, 2020, 3rd up- date. Available from: https://www.worldmusclesociety.org/ news/view/150

33. Association of British Neurologists Guidance on COVID-19 for people with neurological conditions, their doctors and carers. Prepared by The ABN Executive in association with subspecialist Advisory Groups. Version 5, 26 March 2020. Available from: https://cdn.ymaws.com/www.theabn.org/ resource/collection/65C334C7-30FA-45DB-93AA74B3A3A20293/ABN_Neurology_COVID-19_Guidance_ v5_26.3.20.pdf

34. International MG/COVID-19 Working Group; Jacob S, Muppidi S, et al. Guidance for the management of myasthenia gravis (MG) and Lambert-Eaton myasthenic syndrome (LEMS) during the COVID-19 pandemic. J Neurol Sci 2020; 412: 116803. https://doi.org/10.1016/j.jns.2020.116803

\section{A. Klimašauskienė, R. Bunevičiūtė}

\section{MYASTHENIA GRAVIS AND LAMBERT-EATON MYASTHENIC SYNDROME: TREATMENT OPTIONS AND GUIDANCE FOR MANAGEMENT DURING COVID-19 PANDEMIC}

\section{Summary}

Myasthenia gravis (MG) and Lambert-Eaton myasthenic syndrome (LEMS) are immune-mediated neurologic disorders characterized by muscle weakness and fatigue. MG is the most common neuromuscular junction disorder while LEMS is an extraordinary rare disease. The symptomatic treatment of $\mathrm{MG}$ and LEMS includes acetylcholinesterase inhibitors. Amifampridine (3,4-diaminopyridine) is effective in reducing symptoms of the LEMS. Long term immunosuppressive treatment involves corticosteroids, azathioprine, and mycophenolate mofetil. Thymectomy is an essential component of treatment for thymomatous MG patients. Thymectomy also has a therapeutic role for selected non-thymomatous MG patients. The treatment of severe exacerbations and myasthenic crises includes intravenous immunoglobulins and plasma exchange.

During the COVID-19 pandemic, MG/LEMS patients should continue ongoing treatment and are advised not to stop any immunosuppressive agents used. Altering or stopping an immunosuppressive agent may increase disease activity and/or MG exacerbation or crisis. Immune depleting agents should not be given if symptoms and signs of serious infections appear.

Keywords: myasthenia gravis, Lambert-Eaton myasthenic syndrome, therapy, COVID-19.

Gauta:

20200514

Priimta spaudai: 20200608 